\title{
Pengaruh suplementasi vitamin e ( $\alpha$-tokoferol) terhadap kadar gamma glutamil transferase (ggt) dan kadar nitric oxide (no) pada tikus (Studi pada tikus rattus novergicus strain wistar jantan terpapar inhalasi uap benzene)
}

\author{
Roziana $^{1}$, Hertanto Wahyu Subagio ${ }^{2}$, Suhartono $^{3}$, Nyoman Suci Widyastiti ${ }^{4}$
}

\begin{abstract}
Background : Exposure to benzene may cause oxidative stress, one is known as the elevation of GGT and NO levels. Vitamin $E$ can reduce and prevent the products of free radicals. Hydrogen phenolic reactivities to hydroxyl $\alpha$-tocopherol groups be stabilize the uncouples electron in free radicals.

Objective : To prove the effects of vitamin E supplementation on GGT levels and NO levels male rats exposed to benzene vapor Method : Experimental research on animal with controlled group post test only design. Samples were 35 male wistar rats. Samples divided randomly into six groups, consisted of negative control group, positive control group and four groups of gradual doses of vitamin E suplementation $(X 1=1.8 \mathrm{IU} ; \mathrm{X} 2=3.6 \mathrm{IU} ; \mathrm{X} 3=7.2 \mathrm{IU}$ and X4 = $14.4 \mathrm{IU}$ per day for each of 200 gram of body weight of rats). Each of group except negative control group was exposed to 300 ppm of benzene vapor for two weeks (six days on a week and six hours on a day). The measurement of GGT level used Colorimetric Kinetic and Colorimetric Gries method for NO level in each group.

Result : Vitamin E supplementation reduced the level of GGT significantly $(p=0.0001)$. The effect of benzene exposure to elevated levels of GGT can be well prevented by using 14.4 IU for 200 gram body weight per day of vitamin E. Vitamin E supplementation had no reducing levels of $N O$.
\end{abstract}

Conclusion : There was effect of vitamin E supplementation to reduce of GGT level but not to the level of NO.

Keywords: Benzene, vitamin E ( $\alpha$-tokoferol), GGT level, NO level

\section{ABSTRAK}

Latar Belakang : Paparan benzene dapat menyebabkan stres oksidatif, diantaranya ditandai dengan peningkatan kadar GGT dan kadar NO. Vitamin E dapat mengurangi dan mencegah produksi radikal bebas. Reaktivitas hidrogen fenolik pada kelompok hidroksil $\alpha$-tokoferol akan menstabilkan elektron tidak berpasangan pada radikal bebas.

Tujuan : Membuktikan pengaruh suplementasi vitamin E terhadap kadar GGT dan kadar NO pada tikus jantan terpapar uap benzene.

Metode : Penelitian ini adalah penelitian eksperimen pada binatang coba dengan rancangan post test only controlled group design. Sampel 35 ekor tikus strain wistar jantan dibagi secara random dalam enam kelompok yaitu kontrol negatif, kontrol positif dan empat kelompok perlakuan suplementasi vitamin E dosis bertingkat $(X 1=1,8 \mathrm{IU} ; X 2=3,6 \mathrm{IU} ; \mathrm{X} 3=7,2 \mathrm{IU} ;$ dan X4 = 14,4 IU per hari untuk setiap 200 gram berat badan tikus). Setiap kelompok kecuali kontrol negatif dipapar 300 ppm uap benzene selama 2 minggu (6 hari/minggu, 6 jam/hari). Pengukuran kadar GGT menggunakan metoda Kinetik Colorimetric dan kadar NO menggunakan metoda Colorimetric Gries dilakukan pada setiap kelompok.

Hasil : Suplementasi vitamin E berpengaruh menurunkan kadar GGT ( $p=0,0001)$. Pengaruh paparan benzene terhadap peningkatan kadar GGT dapat dicegah dengan baik pada dosis suplementasi vitamin E 14,4 IU/200gr BB tikus/hari. Suplementasi vitamin E tidak berpengaruh terhadap kadar NO.

Simpulan : Ada pengaruh suplementasi vitamin E terhadap penurunan kadar GGT dan tidak ada pengaruh suplementasi vitamin E terhadap penurunan kadar NO.

Kata kunci : Benzene, vitamin E ( $\alpha$-tokoferol), kadar GGT, kadar NO

\section{PENDAHULUAN}

\begin{tabular}{l}
\hline Jurusan Gizi Poltekkes Kemenkes Riau \\
${ }^{2}$ Bagian Ilmu Gizi Fakultas Kedokteran UNDIP \\
Semarang \\
${ }^{3}$ Program Magister Kesehatan Lingkungan Pps UNDIP \\
Semarang \\
${ }^{4}$ Bagian Patologi Klinik Fakultas Kedokteran UNDIP \\
Semarang
\end{tabular}

Benzene $\left(\mathrm{C}_{6} \mathrm{H}_{6}\right)$ adalah salah satu produk yang berasal dari minyak bumi. ${ }^{(1)}$ Secara alami kadar benzene dalam minyak mentah sekitar 4 gram/lt. ${ }^{(2)}$ Aktivitas manusia menggunakan bahan bakar dan produk berbahan benzene akan meningkatkan risiko mulai dari efek narkosis, kerusakan sumsum tulang hingga leukemia myelogenous. ${ }^{(2,3)}$ Aktivitas tersebut meliputi pengolahan produk minyak bumi, batubara, produksi toluena, xilena, dan senyawa aromatik lainnya serta penggunaan benzene pada industri 
diantaranya industri karet, kilang minyak, pom bensin, pabrik kimia dan produsen sepatu. Benzene juga digunakan untuk membuat beberapa jenis pelumas, pewarna, deterjen, obat-obatan, dan pestisida. $^{(2,}$, ${ }^{6}$ Asap rokok merupakan penyebab utama benzene di rumah. ${ }^{(3)}$

The Occupational Safety and Health Administration (OSHA) tahun 2005, memperkirakan sekitar 238.000 pekerja di Amerika Serikat berisiko terkena benzene. ${ }^{(7,8)}$ Hasil penelitian melaporkan konsentrasi benzene udara ambient di lingkungan sekitar depot BBM tinggi, ${ }^{(9)}$ bahkan mobil yang diparkir dengan jendela tertutup terutama dibawah sinar matahari akan terisi benzene hingga 40 kali lipat kadar benzene yang dapat diterima manusia, karena AC mobil mengeluarkan uap benzene dan beberapa komponen interior mobil terbuat dari plastik, kain sintetis dan perekat yang diproduksi menggunakan benzena. ${ }^{(10)}$

Paparan tingkat tinggi benzene merangsang aktivitas CYP2E1 untuk mengoksidasi benzene membentuk metabolit benzene, dan berkonjugasi dengan glutathion sebagai mekanisme pertahanan terhadap senyawa toksik. ${ }^{(1)}$ Gamma glutamyl transferase seluler (GGT) berperan dalam metabolisme ekstraseluler glutation tereduksi (GSH), memungkinkan prekursor asam amino untuk berasimilasi dan dimanfaatkan kembali untuk sintesis GSH intraseluler. Penelitian epidemiologi secara konsisten menunjukkan bahwa peningkatan GGT serum merupakan enzim awal dan sensitif menilai terjadinya stres oksidatif. ${ }^{(12)}$

NO dihasilkan oleh inducible NO synthase ( iNOS) dapat berupa toksik atau pelindung tergantung kondisi, dalam kondisi stres redoks induksi NO berkontribusi terhadap kerusakan hati. Namun, kondisi peradangan akut berhubungan dengan paparan sitokin, NO bertindak sebagai inhibitor poten apoptosis dalam hati. ${ }^{(13)}$

Ketika paparan oksidan dari sumber eksogen tinggi, pertahanan antioksidan tubuh kemungkinan tidak dapat mengatasinya, sehingga diperlukan tambahan antioksidan eksogen baik dari makanan maupun suplemen untuk mengurangi stres oksidatif akibat radikal bebas yang disebabkan oleh unsur dan senyawa dari lingkungan. Salah satu antioksidan eksogen adalah vitamin $\mathrm{E}^{(14)}$

Vitamin E ( $\alpha$-tokoferol) sebagai antioksidan larut lemak, menjadi antioksidan utama dalam membran sel dengan cara melindungi komponen membran sel dari oksidasi radikal bebas. ${ }^{(15-18)}$ Reaktivitas hidrogen phenolik pada C-6 kelompok hidroksil $\alpha$-tokoferol akan menstabilkan elektron tidak berpasangan pada radikal bebas. ${ }^{(19)}$ AKG 2013 untuk vitamin $\mathrm{E}$ adalah $15 \mathrm{IU}^{(20)}$ dan dosis lebih tinggi diyakini diperlukan untuk pencegahan penyakit dan promosi kesehatan, dosis suplementasi yang umum digunakan adalah adalah 100, 200, 400, dan 800 IU. ${ }^{(21)}$ Maka perlu dilakukan penelitian yang bertujuan membuktikan pengaruh suplementasi vitamin $\mathrm{E}$ berbagai dosis terhadap kadar GGT dan kadar NO pada tikus wistar jantan terpapar uap benzene secara akut sebagai upaya preventif mengurangi stres oksidatif.

\section{BAHAN DAN METODE}

\section{Desain, Waktu dan Tempat}

Jenis penelitian experiment dengan rancangan post test only controlled group design, dilaksanakan pada bulan Februari 2014 di Laboratorium Pusat Studi Pangan dan Gizi Universitas Gajah Mada (UGM) Yogyakarta dan Laboratorium GAKY Fakultas Kedokteran Universitas Diponegoro Semarang.

\section{Subjek Penelitian}

Subjek penelitian adalah tikus putih strain wistar jantan berusia 10 - 12 minggu dengan berat \pm 200 gram. Besar sampel dihitung berdasarkan rumus Federer dan diperoleh jumlah sampel per kelompok 5 ekor. Namun, peneliti menggunakan 6 ekor disetiap kelompoknya, kecuali kontrol negatif. Penelitian ini terdiri dari 4 kelompok perlakuan, 1 kontrol positif dan 1 kontrol negatif sehingga total sampel adalah 35 ekor tikus.

\section{Alur Penelitian}

Alur penelitian yaitu sampel terlebih dahulu diadaptasikan selama 3 hari, dikandangkan secara memadai, diberi pakan standar dan minum ad libitum, selanjutnya sampel dipilih berdasarkan kriteria inklusi dan eksklusi. Sampel dibagi menjadi 6 kelompok kecil yang dipilih secara acak, dikandangkan per kelompok dan diberi pakan standar dan minum ad libitum. Analisis kadar GGT dan kadar NO kontrol negatif diperiksa diawal penelitian. Kelompok lainnya diberi paparan benzene $300 \mathrm{ppm}$ selama 2 minggu (6 hari/minggu,6 jam/hari) dalam kandang isolasi. Suplementasi vitamin E diberikan secara oral pada kelompok perlakuan dengan 4 tingkatan dosis $(\mathrm{X} 1=$ $1,8 \mathrm{IU} ; \mathrm{X} 2=3,6 \mathrm{IU} ; \mathrm{X} 3=7,2 \mathrm{IU} ; \mathrm{X} 4=14,4 \mathrm{IU}$ ). Vitamin $\mathrm{E}$ terlebih dahulu dilarutkan dengan 0,25 gram MCT dalam $2 \mathrm{ml}$ aquades. Pada hari ke-15 dilakukan pemeriksaan kadar GGT dengan menggunakan metoda Kinetik Colorimetric dan kadar NO menggunakan metoda Colorimetric Gries, pembacaan pada absorbance $540 \mathrm{~nm}$ ELISA reader.

\section{Pengolahan dan Analisis Data}

Analisis data dengan uji One Way Anova untuk melihat perbedaan antar kelompok, dilanjutkan uji Post Hoc LSD untuk mengetahui perbedaan yang 
signifikan antar setiap kelompok. Data yang tidak berdistribusi normal dilakukan uji non parametrik Kruskal-Wallis dan dilanjutkan uji Mann-Whitney.

\section{HASIL}

Paparan uap benzene dan suplementasi vitamin E dilakukan selama 2 minggu dalam kandang khusus berukuran $50 \times 50 \times 50 \mathrm{~cm}$, sebesar 300 ppm atau $480 \mathrm{mg}$ benzene. Benzene yang digunakan pada penelitian ini adalah benzene produksi Smart Lab Indonesia kemasan 4 liter.Vitamin $\mathrm{E}$ yang digunakan adalah Natur E® 100 IU per kapsul, produksi Decha Care. Vitamin E diberikan secara oral dan setiap dosis perlakuan terlebih dahulu dilarutkan dalam 0,25 gram MCT dengan volume $2 \mathrm{ml} / 200$ gram BB tikus. Tidak ada tikus yang mati selama penelitian berlangsung.

\section{Kadar GGT}

Hasil uji One Way Anova menunjukkan ada perbedaan yang bermakna antara lebih dari 2 kelompok yang diuji $(p=0,001)$. Hasil uji Post-hoc menunjukkan kadar GGT kontrol positif dan semua kelompok perlakuan berbeda secara signifikan dibandingkan dengan kontrol negatif $(p=0,0001)$, kelompok perlakuan $\mathrm{X} 1, \mathrm{X} 2$ dan $\mathrm{X} 3$ berbeda secara signifikan dibandingkan kelompok kontrol negatif $(p=0,0001)$, sedangkan kadar GGT kelompok X4 tidak berbeda secara signifikan dibandingkan kontrol negatif $(p=0,116)$.

Perubahan rerata dibandingkan kelompok kontrol negatif, diketahui semakin meningkat dosis suplementasi vitamin E, semakin menurun kadar GGT. Suplementasi vitamin E berpengaruh menurunkan kadar GGT tikus yang terpapar uap benzene pada dosis 14,4 IU/200 gram BB tikus. Hasil pemeriksaan kadar GGT setiap kelompok perlakuan ditampilkan pada Tabel 1.

Tabel 1. Perbedaan Kadar GGT antar Kelompok Perlakuan

\begin{tabular}{lccccc}
\hline Kelompok & n & $\begin{array}{c}\text { Rerata } \pm \text { SD } \\
(\mathbf{U} / \mathbf{l})\end{array}$ & $\begin{array}{c}\text { Median } \\
(\text { min-mak) }(\mathbf{U} / \mathbf{l})\end{array}$ & $\begin{array}{c}\Delta \\
\text { Perubahan }_{\text {rerata }^{\mathrm{e}}}\end{array}$ & $\boldsymbol{p}$ \\
\hline $\mathrm{K}-$ & 5 & $12,0 \pm 0,21^{\mathrm{c}}$ & $12,8(11,3-12,6)$ & & 0,001 \\
$\mathrm{~K}+$ & 6 & $27,0 \pm 0,42^{\mathrm{a}}$ & $27,0(26,5-27,7)$ & 15,0 & \\
$\mathrm{X} 1$ & 6 & $21,1 \pm 0,64^{\mathrm{a}, \mathrm{c}}$ & $21,1(20,0-21,8)$ & 9,1 & \\
$\mathrm{X} 2$ & 6 & $17,1 \pm 0,26^{\mathrm{a}, \mathrm{c}}$ & $17,1(16,7-17,4)$ & 5,1 & \\
$\mathrm{X} 3$ & 6 & $15,3 \pm 0,40^{\mathrm{a}, \mathrm{c}}$ & $15,4(14,6-15,7)$ & 3,3 & \\
$\mathrm{X} 4$ & 6 & $12,5 \pm 0,51^{\mathrm{c}}$ & $12,4(11,9-13,2)$ & 0,5 & \\
\hline
\end{tabular}

K- = Kontrol negatif, $\mathrm{K}+=$ Kontrol positif, $\mathrm{X} 1=$ Perlakuan I $(1,8 \mathrm{IU}), \mathrm{X} 2=$ Perlakuan II (3,6 IU), X3= Perlakuan III (7,2 IU), X4 = Perlakuan IV (14,4 IU)

Uji One Way Anova, mean $\pm \mathrm{SD}$

Uji Post-Hoc LSD a ${ }^{\mathrm{p}}<0,05$ vs K-; ${ }^{\mathrm{c}} \mathrm{p}<0,05$ vs K+ ${ }^{\mathrm{e}} \Delta \mathrm{K}-$

Tabel 2. Perbedaan Kadar NO antar Kelompok Perlakuan

\begin{tabular}{lccccc}
\hline Kelompok & n & $\begin{array}{c}\text { Rerata } \pm \text { SD } \\
(\mathbf{U} / \mathbf{l})\end{array}$ & $\begin{array}{c}\text { Median } \\
(\text { min-mak) }(\mathbf{u m o l} / \mathbf{l})\end{array}$ & $\begin{array}{c}\Delta \\
\text { Perubahan } \\
\text { median }^{\mathrm{e}}\end{array}$ & $\boldsymbol{p}$ \\
\hline $\mathrm{K}-$ & 5 & $328,0 \pm 51,55$ & $296,1(287,1-395,8)$ & & 0,013 \\
$\mathrm{~K}+$ & 6 & $486,1 \pm 197,95$ & $516,1(223,4-685,8)$ & 220,0 & \\
$\mathrm{X} 1$ & 6 & $622,7 \pm 78,77$ & $658,2(519,9-700,0)^{\mathrm{a}}$ & 362,1 & \\
$\mathrm{X} 2$ & 6 & $465,8 \pm 126,08$ & $488,4(289,1-619,6)$ & 192,3 & \\
$\mathrm{X} 3$ & 6 & $435,8 \pm 44,12$ & $453,0(378,4-478,7)^{\mathrm{a}}$ & 156,9 & \\
X4 & 6 & $415,6 \pm 81,62$ & $409,9(285,8-534,7)$ & 113,8 & \\
\hline
\end{tabular}

$\mathrm{K}-=$ Kontrol negatif, $\mathrm{K}+=$ Kontrol positif, $\mathrm{X} 1=$ Perlakuan $\mathrm{I}(1,8 \mathrm{IU}), \mathrm{X} 2=$ Perlakuan II (3,6 IU), X3= Perlakuan III (7,2 IU), X4 = Perlakuan IV (14,4 IU)

Kruskall-wallis, Median, Mean \pm SD

Mann-Whitney, ${ }^{\mathrm{a}} \mathrm{p}<0,05$ vs $\mathrm{K}-;{ }^{\mathrm{c}} \mathrm{p}<0,05$ vs $\mathrm{K}+$

${ }^{\mathrm{e}} \Delta \mathrm{K}-$ 


\section{Kadar NO}

Hasil uji Kruskal-Wallis menunjukkan setidaknya terdapat perbedaan kadar NO antara dua kelompok $(p=0,013)$. Tidak ada perbedaan yang signifikan antara kelompok perlakuan dengan kontrol positif $(p>0,05)$. Perubahan nilai tengah kadar NO dibandingkan nilai tengah kelompok kontrol negatif, terlihat semakin meningkat dosis suplementasi vitamin E, semakin menurun kadar NO. Namun, nilai perubahan terkecil kadar NO masih cukup besar, maka tidak ada dosis suplementasi vitamin E yang berpengaruh mengendalikan kadar NO.

Hasil pemeriksaan kadar NO setiap kelompok perlakuan ditampilkan pada Tabel 2.

\section{DISKUSI}

\section{Kadar GGT}

Penelitian ini menunjukkan bahwa paparan benzene meningkatkan kadar GGT. Penelitian lain yang menunjukkan adanya hubungan paparan benzene dengan tingkat stres oksidatif yaitu penelitian Hasan et al pada 43 orang pekerja pom bensin terpapar benzene dan 40 orang kontrol, dilaporkan tingkat metabolit benzene pekerja pom bensin lebih tinggi dan menginduksi stres oksidatif, ditandai dengan tingginya kadar MDA dan rendahnya kadar SOD dibandingkan kontrol. ${ }^{(22)}$ Wetmore et al melaporkan tikus terpapar $50 \mathrm{ppm}$ benzene secara sendiri atau bersama antara 50 ppm benzene dan 100 ppm toluena, menunjukkan terjadinya penurunan kadar $\mathrm{GSH} .{ }^{(6)}$

Peningkatan aktivitas GGT merupakan respon pertahanan dari detoksifikasi metabolit toksik hasil produksi proses metabolisme benzene. Aktivitas GGT dan pengaruh paparan benzene dalam metabolismenya berkaitan dengan makromolekular GSH. Paparan tinggi benzene meningkatkan aktivitas sitokrom CYP2E1 mengarah terbentuknya metabolit benzene yang reaktif dan peningkatan pemanfaatan glutathion untuk oksidasi dan konjugasi dengan metabolit reaktif, sehingga menyebabkan terjadinya penurunan kadar GSH. Hal ini menyebabkan metabolit reaktif terlibat dalam siklus redoks dan proses aoutooksidasi membentuk spesies oksigen reaktif.

Metabolisme GSH berkaitan erat dengan siklus Meister $\gamma$-glutamil dimana GGT menghidrolisis GSH menjadi komponen asam amino diantaranya sistein untuk dimanfaatkan kembali pada sintesis GSH intraseluler. ${ }^{(23)}$ Sistein dan glisin jika bereaksi dengan $\mathrm{Fe}^{+3}$ dan $\mathrm{O}_{2}$ membentuk radikal oksigen. ${ }^{(24-26)}$ CYP2E1 adalah superfamily sitokrom $\mathrm{P}_{450}$, yaitu hemoprotein yang mengandung besi dengan atom besi yang berubah-ubah antara $\mathrm{Fe}^{3+}$ dan $\mathrm{Fe}^{2+}$ selama oksidasi reduksi. Besi fero dalam heme mudah mengalami oksidasi oleh superoksida dan agen pengoksidasi

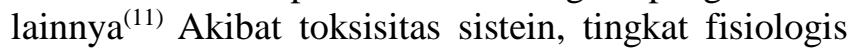

asam amino dalam sel sangat rendah, sedangkan sistein diperlukan untuk biosintesis glutathion seluler. ${ }^{(23,27)}$ Berkurangnya kadar glutathion seluler dan sistein intraseluler diduga menginduksi peningkatan GGT untuk memicu katabolisme GSH.

Penelitian Singh M et al, pada 60 pasien penyakit hati alkoholik dengan riwayat konsumsi alkohol lebih dari 5 tahun dan 20 orang laki - laki sehat sebagai kontrol, melaporkan intake alkohol 80 160 gram perhari meningkatkan stres oksidatif hati, terlihat dari meningkatnya kadar GGT dan MDA serta menurunnya antioksidan GSH dibandingkan kontrol. ${ }^{(23)}$

Suplementasi vitamin E pada penelitian ini terbukti efektif mencegah peningkatan kadar GGT. Hal ini terlihat pada hasil Tabel 1, bahwa semakin meningkat dosis suplementasi vitamin E, semakin menurun kadar GGT. Suplementasi vitamin E efektif mencegah peningkatan kadar GGT pada dosis 14,4 IU /200 gram BB tikus, hasil konversi 800 IU/hari pada manusia.

Penelitian lain oleh Uboh et al, menunjukkan bahwa suplementasi vitamin E dosis $400 \mathrm{IU} / \mathrm{kg}$ dan vitamin C $200 \mathrm{mg} / \mathrm{kg}$ signifikan memberikan efek hepatoprotektif terhadap paparan uap bensin pada tikus $(\mathrm{P} \leq 0,05)$. Vitamin $\mathrm{E}$ dapat mengekspresikan dua fungsi penting dalam membran yaitu mencegah kerusakan ROS pada asam lemak tak jenuh ganda (sebagai antioksidan larut lemak) dan bertindak sebagai agen penstabil membran. Vitamin E juga berperan dalam pemecahan rantai antioksidan, dengan cara mencegah ROS merusak membran sel. ${ }^{(28)}$

Suplementasi vitamin E dalam penelitian ini kemungkinan berperan dalam menghambat dan mengurangi pembentukan radikal bebas dengan menyumbangkan hidrogen dari gugus hidroksil $\left(\mathrm{OH}^{-}\right)$ ke radikal bebas sehingga membuat mereka menjadi tidak aktif. Vitamin E juga mengurangi besi labil sebagai penyebab kerusakan oksidatif. ${ }^{(29)}$ Selain itu vitamin $\mathrm{E}$ diduga memiliki efek protektif terhadap glutathion. ${ }^{(30)}$ Suplementasi vitamin E meningkatkan konsentrasi glutathion seluler, karena vitamin E dapat memodulasi konsentrasi glutathion. Adanya vitamin E maka pemanfaatan gluthation dapat dihemat. ${ }^{(31)}$

\section{Kadar NO}

Hasil penelitian ini menunjukkan paparan inhalasi uap benzene tidak signifikan meningkatkan kadar NO. Hasil penelitian Laskin DL et al, pada tikus yang diinjeksi benzene menunjukkan benzene dapat menekan perkembangan sel sumsum tulang dan secara signifikan meningkatkan kemampuan sel sumsum tulang untuk memproduksi NO guna merespon mediator inflamasi secara tunggal atau kombinasi dengan faktor pertumbuhan hematopoietik. (32) Serangkaian studi di sel HL-60 juga menunjukkan 
bahwa penambahan hidroquinon dan p-benzoquinon menyebabkan peningkatan superoksida dan NO. ${ }^{(33)}$

Adanya paparan benzene telah diketahui menyebabkan terbentuknya radikal bebas seperti superoksida $\left(\mathrm{O}_{2}^{-}\right)$, hidrogen peroksida $\left(\mathrm{H}_{2} \mathrm{O}_{2}\right)$ dan radikal hidroksil $\left(\mathrm{OH}^{-}\right) .{ }^{(33)}$ Adanya radikal bebas akan menginduksi iNOS di makrofag untuk menghasilkan NO dan ROS. ${ }^{(34)}$ iNOS terlibat dalam konversi $L_{-}$ arginin menjadi $\bullet \mathrm{NO}$ dan citrulline. iNOS adalah sitokrom $\mathrm{P}-450$ jenis hemoprotein yang mengandug domain reduktase dan heme pada polipeptida yang sama. (11), (34) Peningkatan kadar NO merupakan mekanisme pertahanan tubuh sebagai sitotoksik terhadap senyawa toksik (benzene dan metabolitnya) dan bagian dari upaya sel dalam menjaga homeostasis terhadap stres oksidatif. (35) Namun, rangsangan produksi NO dan superoksida oleh iNOS dapat menyebabkan pembentukan peroksinitrit $\left(\mathrm{ONOO}^{-}\right)$, suatu perantara reaktif yang diketahui menyebabkan kerusakan protein melalui nitrasi tirosin, triptofan atau residu sistein. ${ }^{(36)}$

Penelitian ini membuktikan bahwa paparan benzene menigkatkan kadar GGT yang berkaitan dengan deplesi GSH dan mengarah terbentuknya radikal bebas sehingga menginduksi iNOS untuk memproduksi NO. ${ }^{(37)}$ NO diketahui juga berfungsi untuk membatasi efek prooksidan karena oksidasi besi. ${ }^{(35)}$ Sementara itu, karakteristik fungsional dari GGT juga dapat mempertahankan tingkat glutathion intraseluler dan mengontrol produksi NO dari GSNO (S-nitroglutathion) melalui pengaturan sel $\mathrm{T}$ dari sistem imun. ${ }^{(37)}$.

Hasil pada Tabel 4 menunjukkan semakin meningkat dosis suplementasi vitamin E, semakin menurun kadar NO. Peran vitamin E dalam penelitian ini diduga dapat mengurangi besi labil yang menyebabkan kerusakan oksidatif. ${ }^{(29)}$ Vitamin E menghambat pembentukan superoksida dan akhirnya mengurangi hidroksil reaktif dan peroksinitrit dengan menyumbangkan hidrogen dari gugus hidroksil $\left(\mathrm{OH}^{-}\right)$ ke radikal bebas dan membuat mereka tidak aktif serta efek protektif terhadap glutathion. ${ }^{(30)}$ Hal ini akan memperbaiki status antioksidan dan juga mengurangi jumlah besi labil mengarah pada penurunan stres oksidatif (penurunan kadar GGT) yang akan diikuti dengan penurunan ekpresi iNOS menghasilkan NO terhadap induksi radikal bebas dan produksi NO dari GSNO.

Dosis suplementasi pada kelompok perlakuan diduga belum memadai untuk menurunkan kadar NO. Suplementasi vitamin E diberikan dengan dosis tinggi sebagai upaya protektif terhadap kondisi toksisitas pada beberapa penelitian hewan coba. Eldien, menggunakan suplementasi vitamin E $100 \mathrm{mg} / \mathrm{kgBB}$ tikus digunakan sebagai proteksi terhadap kondisi cisplatin mielotoksisitas. ${ }^{(39)}$ Uboh et al, menggunakan suplementasi vitamin E $400 \mathrm{IU} / \mathrm{kg}$ pada tikus guna mencegah kerusakan hati akibat induksi uap bensin. ${ }^{(28)}$.

\section{Penerapan dan Pengembangan Hasil Penelitian}

Berdasarkan hasil penelitian telah diketahui bahwa suplementasi vitamin E berpengaruh terhadap penurunan kadar GGT tikus jantan terpapar benzene pada dosis 14,4 IU/200 gram BB tikus. Apabila hasil penelitian ini diaplikasikan ke manusia maka nilai konversi dosis yang digunakan pada manusia adalah $800 \mathrm{IU} / \mathrm{hari}$. Dosis ini adalah dosis yang relatif tinggi jika dibandingkan dengan angka kecukupan gizi sehari yaitu $15 \mathrm{IU} / \mathrm{hari}$.

Vitamin E memiliki efek prooksidan jika dikonsumsi dalam dosis tinggi. ${ }^{(11)}$ Selain itu vitamin E merupakan inhibitor bagi vitamin larut lemak lainnya $(\mathrm{A}, \mathrm{D}, \mathrm{K}) .{ }^{(16,19)}$ Walaupun dosis yang digunakan pada penelitian ini masih dianggap sebagai dosis aman untuk digunakan karena dibawah 1000 IU per hari, akan tetapi jika hasil penelitian ini diterapkan pada manusia, disarankan untuk dilakukan penelitian lanjut untuk menilai efek toksisitasnya.

Metabolisme benzene diantaranya dipengaruhi oleh aktivitas sitokrom p450 terutama CYP2E1, NAD / NADPH dan GSH. Sitokrom p450 merupakan monooksigenase yang mengandung heme. Heme disintesis dari suksinil koA dari siklus asam sitrat, asam amino glisin dan vitamin B6 hingga akhirnya terbentuk protoporfirin. Tahap akhir sintesis heme adalah penggabungan besi fero dengan protoporfirin. $\mathrm{NAD}^{+}$dan $\mathrm{NADP}^{+}$pembentukannya dipengaruhi oleh intake karbohidrat dan niasin. Pembentukan glutathion dipengaruhi oleh asam amino glutamat dan sistein serta mikronutrien selenium.

Adanya interaksi antara zat gizi dalam metabolisme benzene, maka sebaiknya dilakukan penelitian lanjutan pada manusia dengan memperhatikan faktor-faktor zat gizi lain yang ikut berperan terutama tingkat konsumsi zat gizi.

\section{SIMPULAN DAN SARAN}

Suplementasi vitamin E berpengaruh terhadap penurunan kadar GGT pada tikus jantan terpapar uap benzene. Peningkatan kadar GGT dapat dicegah dengan baik pada dosis suplementasi vitamin E 14,4 IU/200 gram BB tikus/hari. Suplementasi vitamin E tidak berpengaruh terhadap pengendalian kadar NO pada tikus jantan terpapar uap benzene. Perlu dilakukan penelitian lebih lanjut untuk menilai efek toksisitas yang mungkin timbul akibat pemberian dosis tinggi vitamin $\mathrm{E}$ dan pertimbangan tingkat asupan zat - zat gizi yang berpengaruh lainnya. 


\section{RUJUKAN}

1. Snyder R, Hedli C. An Overview of Benzene Metabolism. Environmental Health Perspectives. 1996;104 (6).

2. WHO. Preventing disease Through Healthy Envirenments Public Health and Environment. 2010;xx.

3. Klaassen CD. Toxicology The Basic Science Of Poisons. Seventh ed. Kansas: The McGraw-Hill Companies; 2008.

4. Ganguly S, Patra SK, Mandal SK. Effect of Vitamin $\mathrm{E}$ on Benzene Induced Alterations of Some Enzymes of Carbohydrate Metabolism and Oxidative Stress in Rat Liver. International Journal of Chemical Research. 2010;2(2):01-4.

5. Lagorio S, Ferrante D, Ranucci A, Negri S, Sacco P, Rondelli R, Cannizzaro S, Torregrossa MV, Cocco P, Forastiere F, Miligi L, Bisanti L, Magnani C. Exposure to benzene and childhood leukaemia: a pilot case-control study. BMJ Open. 2013;3.

6. Wetmore BA, Struve MF, Pu G, Sharma S, Allison N, Kay CR, Letinski DJ, Nicolich M, Birdd MG, Dorman DC. Genotoxicity of intermittent co-exposure to benzene and toluene in male CD-1 mice. Jcbi. 2008;03.

7. Drew D, Deanna K, Harkins, O'Connor R, Wade FP, Tucker P. Benzene Toxicity. ATSDR. 2006;2001-0003.

8. Wilbur S, Keith S, Faroon O, Wohlers D, Stickney J, Paikoff S, Diamond G, Quinones A. Toxicological Profile For Benzene. Agency for Toxic Substances and Disease Registry Division of Toxicology and Environmental Medicine/Applied Toxicology Branch [serial on the Internet]. 2007; 104 (I) (13).

9. Pudyoko S, Setiani O, Joko T. Hubungan Pajanan Benzene Dengan Kadar Fenol dalam Urin dan Gangguan Sistem Hematopoietic pada Pekerja Instalasi BBM Semarang: Tesis. Program Studi Magister Kesehatan Universitas Diponegoro; 2010.

10. Emery D. Toxic Benzene in Parked Cars. Aboutcom Urban Legends. 2009;xx.

11. Murray R, Granner D, Rodwell V. Biokimia Harper. 27 ed. Jakarta: EGC; 2009.

12. Lee DH, Blomoff R, Jacobs DR. Is Serum Gamma Glutamyltransferase a Marker of Oxidative Stress? Taylor \& Francis Health Science. 2004;38:535-9.

13. Li J, Blialiar TR. Nitric Oxide. The American Physiological Society. 1999;99:1069-73.

14. George MI, Adegoki AO. Effect of Vitamin E on Haemotological in Albino Rats Treated with Gasoline. Journal of Scientific Research. 2012;4:437-44.
15. Almatsier S. Prinsip Dasar Ilmu Gizi. Jakarta: PT Gramedia Pustaka Utama; 2002.

16. Berdanier C. Advanced Nutrition Mikronutrients CRC Press LLC; 1998.

17. Uboh FE, Akpanabiatu M, Alozie Y, Edet EE, Ndem JI, Ebong PE. . Comparative Effect of Vitamins $\mathrm{A}$ and $\mathrm{E}$ on Gasoline Vapours Induced Haemototoxicity and Weight-Loss in Male Rats. International Journal of Pharmacology 20095 (3):215-21.

18. Langseth L. Oxidants, Antioxidants, and Disease Prevension. Brussels: ILSI Europe; 1995.

19. Combs JF. The Vitamins Fundamental Aspects in Nutrition and Health. New York: Elsevier Academic Press; 2008.

20. Menkes RI. Angka Kecukupan Gizi: Menteri Kesehatan Republik Indonesia 2013.

21. Papas AM. Vitamin E: A New Perspective. NutriNews. 2008;9:1-7.

22. Hassan AA, Magd EA, Sahar A, Ghareeb AF, Bolbol SA. Assesment of Oxidative Stress And Antioxidant Status Among Petrol Stations Workers Exposed to Benzene In Zagazig City. ZUMJ. 2013;19 (5).

23. Singh M, Gupta S, Singhal U, Pandey R, Aggarwal SK. Evaluation of the Oxidative Stress in Chronic Alcoholics. Journal of Clinical and Diagnostic Research. 2013;7 (8):1568-71.

24. Lee DH, Steffen LM, Jacobs DR. Association between serum -glutamyltransferase and dietary factors: the Coronary Artery Risk Development in Young Adults (CARDIA) Study1-3. American Society for Clinical Nutrition. 2004;79:600-5.

25. Cho YG, Park KH, Kim CW, Hur YI. Gammaglutamyltransferase and Children's Overweight. Korean J Fam Med. 2011;32 (3):182-8.

26. Lee DH, Gross MD, Jacobs DR. Association of Serum Carotenoids and Tocopherols with Glutamyltransferase: The Cardiovascular Risk Development in Young Adults (CARDIA) Study. Clinical Chemistry. 2004;50 (3):582-8.

27. Castellano I, Merlino A. Gamma-Glutamyl Transpeptidases:Structure and Function. SpringerBriefs in Biochemistry and Molecular Biology. 2013;XX.

28. Uboh FE, Eong PE, Akpan HD, Usoh IF. Hepatoprotective effect of vitamins $\mathrm{C}$ and $\mathrm{E}$ against gasoline vapor-induced liver injury in male rats. Turk J Biol. 2012;36:217-23.

29. Chow CK, Johnson H. Antioxidant Function and Health Implications of Vitamin E. The Open Nutrition Journal. 2013;7(1874-2882/13):1-6.

30. Haaften RI, Haenen GR, Evelo CT, Bast A. Effect of vitamin $\mathrm{E}$ on glutathione-dependent enzymes. Drug Metabolism Reviews. 2003;35 (23):215 - 53. 
31. Jain SK, Mcvie R, Smith T. Vitamin E Supplementation Restores Glutathione and Malondialdehyde to Normal Concentrations in Erythrocytes of Type 1 Diabetic Children. Diabetes Care. 2000;23 (2):1389-94.

32. Laskin DL, Heck DE, Punjabi CJ, Laskin JD. Role of Nitric Oxide in Hematosuppression and Benzene-induced Toxicity. Environmental Health Perspectives. 1996;104:1283-7.

33. Snyder R. Leukemia and Benzene. International Journal of Environmental Research and Public Health. 2012;xx.

34. Melikian A, Chen K, Li H, Sodum R, Fala E, Bayoumy $\mathrm{K}$. The role of nitric oxide on DNA damage induced by benzene metabolites. Oncology Reports. 2008;19:1331-7.

35. Clemens MG. The Liver: Biology and Pathobiology Charlotte: Department of Biology, University of North Carolina; 2001.

36. Soneja A, Drews M, Malinski T. Role of nitric oxide, nitroxidative and oxidative stress in wound healing. Pharmacological Reports. 2005;57:10819.

37. Atakisi E, Atakisi O, Topcu B, Uzun M. Effects of therapeutic dose of ivermectin on plasma nitric oxide and total antioxidant capacity in rabbits. European Review for Medical and Pharmacological Sciences. 2009;13:425-9.

38. Cornejo P, Varela P, Videla LA, Fernandez V. Chronic iron overload enhances inducible nitric oxide synthase expression in rat liver. PubMed. 2005;13 (1):54-61.

39. Eldien HMS. The Possible Role of Vitamin E on Bone Marrow Cytogenic of Cisplatin In Adult Male Albino Rat. The Egyptian Journal Of lHistology. 2005;28 (2):79 - 186.

40. Patrick L. Lead Toxicity Part II: The Role of Free Radical Damage and the Use of Antioxidants in the Pathology and Treatment of Lead Toxicity. Alternative Medicine Review. 2006;11:114-27. 